\title{
Clinic Features, Follow-up and Treatment Options of Acute Paronychia in Children: Hacettepe University Experience
}

\author{
Çocuklarda Akut Paronişi Klinik, Takip ve Tedavisi: \\ Hacettepe Üniversitesi Deneyimi
}

\author{
Kübra Cebeci' ${ }^{1}$ Kübra Aykaç², Yasemin Özsürekci², Sevgen Tanır Başaranoğlu², Ali Bülent Cengiz², Ateş Kara², \\ Mehmet Ceyhan² \\ ${ }^{1}$ Department of Pediatrics, Hacettepe University School of Medicine, Ankara, Turkey \\ 2 Department of Pediatric Infectious Diseases, Hacettepe School of Medicine, Ankara, Turkey
}

Cite this article as: Cebeci K, Aykaç K, Özsürekci Y, Tanır Başaranoğlu S, Cengiz AB, Kara A, et al. Clinic features, follow-up and treatment options of acute paronychia in children: Hacettepe University experience. J Pediatr Inf 2019;13(1):e55-e59

\section{Abstract}

Objective: Paronychia, the inflammation of proximal and lateral nail folds and, is the most commonly encountered hand infection. In this study, it was aimed to evaluate the clinical features and treatment options of paronychia in our center.

Material and Methods: Patients diagnosed with acute paronychia from June 2014 to December 2016 in the Pediatric Infectious Disease Department of Hacettepe University İhsan Doğramacı Children Hospital were included into the study. Patients' age, gender, underlying disease, physical examination findings, laboratory parameters, hospitalization status, treatment choices (surgery/antibiotic treatment) and durations, and complications were evaluated.

Results: Seventy-five patients (37 male, 49.3\%) with a median age of 8 years $(0-18)$ were enrolled into the study. The patients were divided into two groups as immunocompetent $(62,82.7 \%)$ and immunocompromised (primary or secondary immunodeficiency, 13, 17.3\%). Two of the immuncompromised patients (14.3\%) and eight of immunocompetent patients underwent surgery drainage because of abscess formation. Five patients were hospitalized, three of whom (21.4\%) were immunocompromised and two of whom (3.3\%) were immunocompetent $(p=0.01)$.

Conclusion: Immune response of the patients diagnosed with paronychia is the main guide for treatment and follow plan.

Keywords: Children, paronychia, immunocompromised patients
Öz

Giriş: Tırnağı çevreleyen epidermisin enfeksiyonu olan paronişi, elin en sık görülen enfeksiyonudur. Çalışmamızda hastanemizde paronişi tanısı alan hastaların klinik özelliklerini ve tedavilerini tartışmayı planladık.

Gereç ve Yöntemler: Bu çalışmada Haziran 2014 ve Aralık 2016 tarihleri arasında, Hacettepe Üniversitesi İhsan Doğramacı Çocuk Hastanesi Enfeksiyon Hastalıkları Bilim Dalı Polikliniği'nde akut paronişi tanısı konulan çocuk hastalar dahil edildi. Hastaların yaşı, cinsiyeti, varsa altta yatan hastalık, fizik muayene bulguları, laboratuvar bulguları, hastaneye yatırılıp yatırımadıkları, yatış süresi, uygulanan tedaviler (cerrahi veya antibiyoterapi), komplikasyon varlığı ve aldığı antibiyoterapi süreleri değerlendirildi.

Bulgular: Çalışmamızda, akut paronişi tanısı konulan 75 olgunun 37 (\%49.3)'si erkek, 38 (\%50.7)'i kız ve ortanca yaşları 8 yıl (en küçük ve en büyük, 0-18) idi. Hastalar, altta yatan hastalıklara göre immünyetmezliği olan ve olmayanlar olmak üzere iki gruba ayrıldığında, 13 (\%17.3)'ünde immünyetmezlik tespit edilirken (primer veya sekonder) 62 (\%82.7)'sinde immünyetmezlik tespit edilmedi. Toplam 10 hastaya paronişiye eşlik eden apse olması üzerine drenaj yapıldı. İmmünyetmezliği olan hastaların \%14.3 ( $n=$ 2)'üne, immünyetmezlik olmayanların ise $\% 13.1(n=8)$ 'ine apse gelişmesi nedeniyle cerrahi drenaj gerekti. Hastaneye yatarak tedavi edilen toplam 5 hasta vardı. İmmünyetmezlikli olan hastaların \%21.4 $(n=3)^{\prime}$ ü, olmayan hastaların ise \%3.3 ( $n=2)^{\prime}$ 'ü hastanede yatarak tedavi edildi. Bu iki grup arasında hastanede yatış açısından istatistiksel anlamlı fark vardı $(p=0.01)$.

Sonuç: Paronişi tedavi planında konağın immün cevabı hastaların izlemi ve tedavisinin düzenlenmesi için temel yol göstericidir.

Anahtar Kelimeler: Çocuk, paronişi, immünyetmezlik

Yazışma Adresi / Correspondence Address

Kübra Cebeci

Hacettepe Üniversitesi Tıp Fakültesi,

Çocuk Sağlığı ve Hastalıkları Anabilim Dalı,

Ankara-Türkiye

E-mail: cebecikubramd@gmail.com 


\section{Introduction}

Hands are highly susceptible to infections due to their anatomy, functions and the fact that they are exposed to many pathogens in our daily lives. Paronychia is the most commonly seen infection of the hand (1-3). Paronychia, the infection surrounding the epidermis of the nail, develops typically following the deterioration of the nail plate and the adjacent nail fold. Even though it manifests most commonly secondary to trauma, it can additionally develop due to multiple infectious or non-infectious reasons (chemical irritants, excessive humidity, drugs, and systemic diseases) (4-6). If it lasts less than six weeks or more than six weeks, it is evaluated as acute paronychia and chronic paronychia, respectively. While the most common agent is Staphylococcus aureus, fungi, mixed aerobes and anaerobe bacteria can be agents, as well $(4,5)$. Acute paronychia is treated with warm soaks, Burow's solution (aluminum acetate), povidone iodine, topical chlorhexidine, and systemic treatments. In the event of an abscess formation, surgical drainage can be necessary $(4,5)$.

Unless paronychia is treated efficiently, secondary complications like osteomyelitis and sepsis can develop (4). The immune response of the host is one of the major determinants of the spread of the infection that could lead to the development of complications and a guide both to the monitoring of the patient and to the regulation of the treatment. There are very limited number of studies investigating the relation of the immune-response of the host and the course of the disease in acute paronychia (6). In this study, it was aimed to discuss the frequency of paronychia and its clinical approach in our center and to investigate the effect of the host's immune system disorder on the clinical picture.

\section{Materials and Methods}

Patients under the age of 18 diagnosed with acute paronychia from June 2014 to December 2016 in the Pediatric Infectious Disease Department of Hacettepe University Iinsan Doğramacı Children Hospital were included into the study. Age, gender, underlying diseases, physical examination findings, laboratory findings [(full blood count, C-reactive protein (CRP), erythrocyte sedimentation rate (ESR)], hospitalization status, hospitalization duration, implemented treatments (surgery or antibiotherapy), complication development, and antibiotherapy duration were retrospectively reviewed from the patient files on the computer database of our hospital.

SPSS version 21.0 (SPSS, Inc., Chicago, IL, USA) was used for the statistical analyses of the data. While median and minimum-maximum values were used for continuous variables defining basic patient demographics, frequency distributions were used for categorical variables. Since data mostly consisted of categorical variables, Chi-square test was used in the comparison of the data of the patients with paronychia. Fisher's Exact text was used for the continuous variables that needed to be compared, and in cases where case number was limited and that did not fit normal distribution, Mann-Whitney $U$ test was used. $p$ under 0.05 was accepted for statistical significance.

\section{Results}

Out of the 75 cases diagnosed with acute paronychia in our polyclinic, 37 (49.3\%) were male, 38 (50.7\%) were female, and the median age was 8 years $(0-18)$ (Table 1,2). Paronychia was seen on the toe for 18 and finger for 57 patients. When the patients were divided into two groups as those with immunodeficiency and those without according to their underlying diseases, 13 (17.3\%) were confirmed with immunodeficiency (primary and secondary) and 62 (82.7\%) were not. Female to male ratio in the immunodeficient group was $6: 7$ and 31:31 in the group without immunodeficiency. There was not a statistically significant difference between the two groups in terms of age and gender ( $p=0.86$ and $p=0.59$, respectively).

Drainage was performed on 10 patients with accompanying abscess to paronychia. Surgical drainage was required in $14.3 \%(n=2)$ of the immunodeficient patients and in $13.1 \%$ $(n=8)$ of the patients without immunodeficiency. Antibiotic treatment was also given to patients that required drainage. There were five hospitalized patients in total. $21.4 \%(n=3)$ of the immunodeficient patients and $3.3 \%$ of the patients without immunodeficiency were treated as inpatients. There was a statistically significant difference in terms of hospitalization between the two groups $(p=0.01)$. One of the patients with immunodeficiency was receiving chemotherapy for neuroblastoma and was neutropenic; the other had a non-Hodgkin's lymphoma and received chemotherapy the same day and was at risk of developing neutropenia; and the other patient was diagnosed with common variable immunodeficiency and was not respondent to oral antibiotics. Cellulite was formed in the fingers of the patients despite oral antibiotic treatment monitored as out patients in patients without immunodeficiency requiring hospitalization. Complications developed in only $4 \%(n=3)$ of all patients, cellulite was found in all of their feet and none of these patients had immunodeficiency.

When groups with and without immunodeficiency were compared in terms of acute phase responses, mean white blood cell count (WBC) was detected lower in patients with immunodeficiency when compared to those without $(p=0.65)$. CRP and its value and ESR were determined higher in immunodeficient patients in comparison to immunocompetent ones $(p=0.001$ and $\mathrm{p}=0.001$, respectively).

Antibiotic treatment was given to all patients. Patients in the immunodeficient group received antibiotic treatment 
Table 1. Comparison of the groups with and without immunodeficiency

\begin{tabular}{|c|c|c|c|c|}
\hline & $\begin{array}{c}\text { Total } \\
(n=75)\end{array}$ & $\begin{array}{c}\text { Patients with } \\
\text { immunodeficiency }(n=13)\end{array}$ & $\begin{array}{c}\text { Patients without } \\
\text { immunodeficiency }(n=62)\end{array}$ & $\mathbf{p}$ \\
\hline Age (median, minimum-maximum) & $8(0-18)$ & $10(1-18)$ & $7(0-17)$ & 0.86 \\
\hline Hospitalization & $5(6.7)$ & $3(21.4)$ & $2(3.3) 2(3.3)$ & 0.01 \\
\hline Surgical treatment (drainage) & $10(13.3)$ & $2(14.3)$ & $8(13.1)$ & NA \\
\hline $\begin{array}{l}\text { Treatments } \\
\text { Only local treatment } \\
\text { Systemic treatment } \\
\text { AMC } \\
\text { MET+ AMC } \\
\text { DA+ AMC } \\
\text { AC + AMC } \\
\text { AC + MET + AMC } \\
\text { OR + AMC } \\
\text { SAM } \\
\text { DA + SAM } \\
\text { Other }\end{array}$ & $\begin{array}{c}1(1.3) \\
74(98.7) \\
42(56) \\
2(2.7) \\
6(8) \\
4(5.3) \\
1(1.3) \\
6(8) \\
6(8) \\
2(2.7) \\
5(6.7) \\
\end{array}$ & $\begin{array}{c}0 \\
0 \\
6(46.2) \\
1(7.1) \\
2(15.4) \\
0 \\
0 \\
0 \\
0 \\
2(15.4) \\
2(15.4) \\
\end{array}$ & $\begin{array}{c}1(1.6) \\
1(98.4) \\
36(58.1) \\
1(1.6) \\
4(6.5) \\
4(6.6) \\
1(1.6) \\
6(9.7) \\
6(9.7) \\
0 \\
3(4.8) \\
\end{array}$ & NA \\
\hline Period of treatment (day) & $10(5-21)$ & $10(10-21)$ & $10(5-20)$ & 0.93 \\
\hline
\end{tabular}

Table 2. Spectrum of immunodeficient patients

\begin{tabular}{|l|c|c|c|}
\hline Disease & Number of patients & Surgical drainage & Hospitalization \\
\hline Primary immunodeficiency associated with chronic diarrhea & 1 & No & No \\
\hline Common variable immunodeficiency & 1 & Yos & No \\
\hline Cyclic neutropenia & 1 & No & No \\
\hline Acute leukemia & 3 & Yes & Yes \\
\hline Non-Hodgkin's lymphoma & 1 & No & Nes \\
\hline Neruroblastoma & 1 & No & No \\
\hline Juveinle idiopathic arthritis & 2 & No & No \\
\hline Kidney transplant receiver & 1 & No & No \\
\hline Systemic lupus erythematosus & 1 & & No \\
\hline Type 1 diabetes mellitus & 1 &
\end{tabular}

for a mean of ten days (10-21 days) and the patients without immunodeficiency received the same treatment for a mean of ten days (5-20 days), and a significant difference was not confirmed between the two groups ( $p>0.05) .56 \%(n=42)$ of all patients received amoxycillin-clavulanic acid; $8 \%(n=6)$ received amoxycillin-clavulanic acid and clindamycin; $8 \%$ was given $(n=6)$ amoxycillin-clavulanic acid and ornidazole; $8 \%$ $(n=6)$ was given sulbactam ampicillin; $5.3 \%(n=4)$ received amoxycillin-clavulanic acid and acyclovir; $2.7 \%(n=2)$ received sulbactam ampicillin and clindamycin; $1.3 \%(n=1)$ received amoxycillin-clavulanic acid, metronidazole and acyclovir; and $1.3 \%(n=1)$ received topical care. The most commonly used antibiotic in both groups was amoxycillin clavulanate, which was given to $46.2 \%(n=6)$ of the immunodeficient patients and $58.1 \%(n=36)$ of the immunocompetent patients. Pus culture could only be sent from four patients, one of which grew methicillin-susceptible Staphylococcus epidermidis, the other grew Acinetobacter baumannii and no growth was found in the other. The patient with Acinetobacter growth had had a history of hydronephrosis and antibiotic treatment with a diagnosis of omphalitis in an epicenter recently. Acyclovir was added to the treatment of the patients who were considered to clinically develop herpetic panaris. Furthermore, multiple antibiotic treatment was preferred in the treatment of the 
patients who had priorly received oral treatment because of panaris or who had had erysipelas or cellulite that spread to the finger or hand subsidiary to paronychia.

\section{Discussion}

When the literature was reviewed, it was found that there had been a limited number of studies regarding paronychia in childhood and that the publications mostly covered adults (7-11). We retrospectively reviewed the clinical and laboratory data of child cases with paronychia that we observe at a considerable rate in our clinical practice. The most important finding in this study was that the rate of hospitalization in immunodeficient patients was higher than those without immunodeficien$c y$, which is in accordance with the data of Infectious Diseases Society of America. As it is known, skin and soft tissue infections contribute significantly to the mortality and morbidity of immunodeficient patients (12-15). Therefore, Infectious Diseases Society of America recommends hospitalization for the treatment of cellulite in outpatients unresponsive to treatment or patients with severe immunodeficiency (2).

In a study by Rabarin et al. with 103 cases with acute finger infections, it has been reported that all received drainage, $23.3 \%$ received antibiotics additionally, $3.8 \%$ of the patients underwent chemotherapy, $1.9 \%$ had diabetes mellitus, $0.9 \%$ had a diagnosis of scleroderma, and $0.9 \%$ had been using steroids (16). The same publication has also pointed out that the success of especially surgery and/or antibiotherapy was discussed, all patients recovered without sequalae, and that the most frequently isolated microorganisms were methicillin-susceptible Staphylococcus aureus (MSSA) and polymicrobial microorganisms. Pierrart et al. have similarly detected MSSA as the most frequent agent in the pus cultures of patients with paronychia (17). Two of the three agents confirmed in our study were methicillin-susceptible staphylococci. However, increasing methicillin resistance in staphylococcus infections in childhood should be kept in mind (12).

All patients in our study received antibiotic treatment, and only ten required surgical treatment due to abscess formation. Surgical treatment is not needed in early paronychia (1). However, it has been put forth that surgical drainage is needed if abscess formation has also occurred in skin and soft tissue infections, but addition of antibiotherapy to the treatment is still controversial (12). The antibiotic treatments given both cause resistant bacteria and increase the cost of treatment. There are a couple of studies that evaluate the benefit of surgical drainage and antibiotics in the treatment of paronychia (17). Pierrart et al. have claimed that very good results are obtained by only surgical treatment and recurrence rate is low. Only in one of their patients, the treatment was unsatisfactory due to unsuitable surgery. It has also been emphasized that antibiotics do not play part in treatment in patients without risk of complicated paron- ychia (17). In the treatment of patients with immunodeficiency, antibiotics are crucial besides surgery (18). All of our patients undergoing surgery also received antibiotic treatment.

In our study, the levels of ESR and CRP, which are indicators of acute phase response, were detected to be significantly different in the groups with and without immunodeficiency, which shows that CRP is a significant parameter in the event of an infection in immunodeficient patients $(19,20)$. CRP and ESR, which are conventional acute phase reactants, are indicators of increasing inflammation in both infectious and non-infectious cases. CRP is a more specific acute phase reactant than sedimentation. In our study, both CRP and sedimentation were detected significantly high in immunodeficient patients, which can be linked to underlying non-infectious diseases (21). Moreover, it was once more understood with this study that they could be quite functional and directive indicators in our clinical practice since they are simple, fast and easily performed examinations.

Though rarely, complications such as osteomyelitis, sepsis and pericarditis secondary to paronychia have been reported in the literature $(22,23)$. This group of patients is monitored with closer follow-ups in our clinical practice due to the risk of systemic infection and septicemia in patients with immunodeficiency $(1,2,16,24)$. Cellulite secondary to paronychia was determined to have developed in the feet of three patients in this study.

There are some limitations to our study. Firstly, data could not be generalized to whole population since the sample population was small and covered a single center. Secondly, all data that we wished to assess could not be reached as this was a retrospective study. On the other hand, since pus culture could not be sent from all patients to whom surgical drainage was performed, information on the relation between the agent and the prognosis could not be reached. Therefore, it is to our belief that prospective studies should be carried out on paronychia follow-up and treatment (antibiotic/surgery) which we, physicians, come across very frequently in daily practice. However, we believe that our study is of outmost importance since it provides insight regarding paronychia in children.

To conclude, even though our study does not reflect the whole population, it is vital for the fact that the patients are children and these are the data of our hospital, which is a third care reference center. Paronychia is a commonly seen infection in childhood, and the immune response of the host is a fundamental guide in the follow-up of the patients and treatment regulation since it is a primary indicator of the spread of the infection. Accordingly, a more conservative approach and appropriate antibiotherapy will diminish the use of unnecessary antibiotics in patients with sufficient immune response. In immunodeficient patients, closer clinical follow-ups will be effective in preventing the development of secondary complications. 
Ethics Committe Approval: Ethics committee approval was received. Informed Consent: Patient concent was obtained.

Peer-review: Externally peer-reviewed.

Author Contributions: Concept - YÖ, KA, KC; Design - YÖ, KA, KC; Supervision - AK, YÖ, ABC; Materials - YÖ, KA, KC; Data Collection and/ or Processing - KA, KC; Analysis and/or Interpretation - YÖ, KA, KC; Literature Review - YÖ, KA, KC; Writing - KA, KC; Critical Review - All of authors.

Conflict of Interest: No conflict of interest was declared by the authors.

Financial Disclosure: The authors declared that this study has received no financial support.

\section{References}

1. Kall S, Vogt PM. Surgical therapy for hand infections. Part I. Chirurg 2005;76:615-25.

2. Stevens DL, Bisno AL, Chambers HF, Dellinger EP, Goldstein EJ, Gorbach $S L$, et al. Practice guidelines for the diagnosis and management os skin and soft tissue infections: 2014 update by the Infectious Diseases Society of America. Clin Infect Dis 2014;59:e10-52.

3. Franko Ol, Abrams RA. Hand infections. Orthop Clin North Am 2013;44:625-34.

4. Rigopoulos D, Larios G, Gregoriou S, Alevizos A. Acute and chronic paronychia. Am Fam Physician 2008;77:339-46.

5. Rockwell PG. Acute and chronic paronychia. Am Fam Physician 2001;63:1113-6.

6. Shafritz $A B$, Coppage JM. Acute and chronic paronychia of the hand. $J$ Am Acad Orthop Surg 2014;22:165-74.

7. Raje N, Dinakar C. Overview of immunodeficiency disorders. Immunol Allergy Clin North Am 2015;35:599-623.

8. Jebson PJ. Infections of the fingertip. Paronychias and felons. Hand Clin 1998; 14: 547-55.

9. Silverman RA. Diseases of the nails in infants and children. Adv Dermatol 1990;5:153-70.

10. Brook I. Bacteriologic study of paronychia in children. Am J Surg 1981;141:703-5.

11. Ritting AW, O'Malley MP, Rodner CM. Acute paronychia. J Hand Surg Am 2012;37:1068-70
12. Williams DJ, Cooper WO, Kaltenbach LA, Dudley JA, Kirschke DL, Jones $T F$, et al. Comparative effectiveness of antibiotic treatment strategies for pediatric skin and soft-tissue infections. Pediatrics 2011;128:e47987.

13. Kosmidis $\mathrm{Cl}$, Chandrasekar PH. Management of gram-positive bacterial infections in patient with cancer. Leuk Lymphoma 2012;53:8-18.

14. Edelsberg J, Taneja C, Zervos M, Haque N, Moore C, Reyes K, et al. Trends in US hospital admissions for skin and soft tissue infections. Emerg Infect Dis 2009;15:1516-8.

15. Burke VE, Lopez FA. Approach to skin and soft tissue infections in nonHIV immunocompromised hosts. Curr Opin Infect Dis 2017;4:354-63.

16. Rabarin F, Jeudy J, Cesari B, Petit A, Bigorre N, Saint-Cast Y, et al; Orthopedics and Traumatology Society of Western France (SOO)2. Acute finger-tip infection: Management and treatment. A 103-case series. Orthop Traumatol Surg Res 2017;103:933-6.

17. Pierrart J, Delgrande D, Mamane W, Tordjman D, Masmejean EH. Acute felon and paronychia: Antibiotics not necessary after surgical treatment. Prospective study of 46 patients. Hand Surg Rehabil 2016;35:40-

18. Liu C, Bayer A, Cosgrove SE, Daum RS, Fridkin SK, Gorwitz RJ, et al; Infectious Diseases Society of America. Clinical practice guidelines by the infectious diseases society of america for the treatment of methicillin-resistant Staphylococcus aureus infections in adults and children. Clin Infect Dis 2011;52:e18-55 (Erratum in: Clin Infect Dis 2011;53:319).

19. Grønn M, Slørdahl SH, Skrede S, Lie SO. C-reactive protein as an indicator of infection in the immunosuppressed child. Eur J Pediatr 1986:145:18-21.

20. de Oliveira VM, Moraes RB, Stein AT, Wendland EM. Accuracy of C - Reactive protein as a bacterial infection marker in critically immunosuppressed patients: A systematic review and meta-analysis. J Crit Care 2017:42:129-37.

21. Markanday A. Acute phase reactants in infections: evidence-based reviewand a guide for clinicians. Open Forum Infect Dis 2015;3:23.

22. Bansal N, Walters HL, Kobayashi D. Purulent pericarditis due to paronychia in a 16-month-old child: a nail-biting story. World J Pediatr Congenit Heart Surg 2018:2150135117742651.

23. Mauriello CT, Raustol OA, Aguiar MA, Cunnion KM. An 11-year-old male with refractory osteomyelitis. Case Rep Pediatr 2012;2012:285980.

24. Suaya JA, Eisenberg DF, Fang C, Miller LG. Skin and soft tissue infections and associated complications among commercially insured patients aged 0-64 years with and without diabetes in the U.S. PLoS One 2013;8:e60057. 